\title{
Redução de fratura de olécrano em equino com fixação de placa dinâmica de compressão, parafusos e porcas de bloqueio
}

Lívia Zampol Dell' Antonia, Lilian Cristina Morais Boneberg

*Autor correspondente

e-mail: lilianboneberg@hotmail.com

\section{Resumo}

As fraturas de olécrano são relativamente comuns em equinos e suas causas mais frequentes relacionam-se ao trauma externo originado, principalmente, por coices ou quedas. Assim como em qualquer modalidade de esporte, os equinos estão sujeitos a sofrer certos tipos de acidentes, que podem ser desde uma simples luxação até uma fratura exposta. Os sinais clínicos geralmente associados à fratura de olécrano são manifestados como incapacidade de o animal suportar o peso sobre o membro lesionado, assim como uma postura de "cotovelo caído". Uma pequena porcentagem dos animais é capaz de suportar seu peso, apresentando dessa maneira diferentes graus de claudicação. 0 objetivo deste trabalho é descrever o tratamento cirúrgico realizado com princípios da osteossíntese, juntamente à colocação de placa dinâmica de compressão (DCP), parafusos e porcas Screw locking elements (SLE), em um equino com 10 anos de idade, raça Sela Francesa, utilizado em concursos de equitação, que fraturou o olécrano do membro anterior esquerdo após sofrer um trauma. Foram realizadas pesquisas eletrônicas e bibliográficas em artigos científicos e livros; esclarecimentos relativos ao tratamento empregado e prognóstico são discutidos e comparados às doutrinas consultadas nesse relato de caso. Sabe-se que o insucesso das osteossínteses com placas convencionais ocorre devido aos parafusos se afrouxarem. Para melhorar a estabilidade, a fixação foi realizada com porcas de bloqueio na extremidade dos parafusos e SLE. Sabe-se que apenas uma SLE de cada lado da fratura, estabilizada com placa de compressão dinâmica, proporciona a mesma firmeza como se todos os parafusos estivessem bloqueados com porca de bloqueio. Alguns autores afirmaram que enquanto os sistemas de placa de bloqueio (LCP) não obtinham micromovimento no foco da fratura, com placas dinâmicas de compressão fixadas com SLE em cada extremidade, o micromovimento foi menor do que um milímetro, sendo ideal para estimular a formação de calo ósseo. A porca de bloqueio colocada na extremidade do parafuso fixa melhor a placa de compressão dinâmica, pois não depende da rosca feita no 
osso, suportando quase a mesma carga que o osso natural e sendo mais satisfatória que as osteossínteses tradicionais, onde a rosca é realizada no próprio osso. Para um paciente que necessite colocar peso imediato sobre o osso fraturado, este método pode ser mais plausível do que outros métodos de fixação, não sendo necessária a colocação de porcas em todos os parafusos. 0 tratamento cirúrgico empregado foi bem sucedido, com consolidação completa da fratura.

Palavras-chave: Osteossíntese. Fratura. Olecrano. 